\title{
Liver resection with a new technique
}

\author{
Karaciğer rezeksiyonunda yeni bir teknik \\ Mustafa Turan*, Kürşat Karadayı, Metin Şen, Çınar Yastı, Sinan Soylu, Yaşar \\ Özdenkaya, Cevdet Düger, Cemil İ́sbir
}

Department of General Surgery (Prof. M. Turan, MD, Prof. K. Karadayı, MD, Prof. M. Şen, MD), Department of Anesthesiology (Assist. Prof. C. Düger, MD, Assist. Prof. C. İsbir, MD), Cumhuriyet University School of Medicine, TR-58140 Sivas, Department of General Surgery (Assist. Prof. Ç. Yast1, MD), Numune Education and Research Hospital, TR-06100 Ankara, Department of General Surgery (S. Soylu, MD), Sivas Medical Center, TR-58140 Sivas, Department of General Surgery (Assist. Prof. Y. Özdenkaya, MD), Medipol University School of Medicine, TR-34557 İstanbul

\begin{abstract}
Aim. In this retrospective study, we scrutinized the patients in whom we had used RadioFrequency $(\mathrm{RF})$ technique in liver resection procedures. Methods. In this retrospective study, indications for liver resection were malignant tumors in 17 (Elective cases) and 6 patients with trauma etiology (Emergency cases). Results. Left lateral segmentectomy (segments II-III) was done in 9 patients. Segment VI resection was performed in 4 patients. Non-anatomical (wedge) resections were done in 10 patients. The average time necessary for transection of the liver parenchyma was $34 \pm 5$ min. in Elective group and $37 \pm 5 \mathrm{~min}$. in Emergency group. Average blood loss was $32 \pm 5 \mathrm{~mL}$ in Elective group and $89 \pm 8 \mathrm{~mL}$ in Emergency group. In the postoperative period, we did not see any subcapsular or perihepatic hematoma responsible for delayed hemorrhage. No signs of infectious disease or abscesses were observed. Conclusion. This RF assisted technique is effective in bloodless liver resections.
\end{abstract}

Keywords: Radio-Frequency, liver resection, hepatoma, trauma

\section{Özet}

Amaç. $\mathrm{Bu}$ çalışmada kliniğimizde karaciğer rezeksiyonunda Radio-Frekans (RF) tekniğinin uygulandığı hastalar irdelenmiştir. Yöntem. Bu retrospektif çalışmaya karaciğer rezeksiyonu uygulanan karaciğer tümörü olan 17 hasta (Elektif grup) ve karaciğer travması 6 hasta (Acil grup) dahil edilmiştir. Bulgular. Dokuz hastaya sol lateral segmentektomi (segment II-III) uygulanırken, Segment VI reseksiyonu 4 hastada uygulamıştır. Wedge reseksiyon 10 hastaya uygulanmıştır. Elektif grupta karaciğer parenkim rezeksiyonu için gereken ortalama zaman $34 \pm 5$ dakika iken Acil grupta $37 \pm 5$ dakika idi. Ortalama kan kaybı Elektif grupta $32 \pm 5 \mathrm{~mL}$ iken acil grupta $89 \pm 8 \mathrm{~mL}$ idi. Ameliyat sonrası dönemde subkapsüler veya perihepatik hematom gelişmemiştir. Yine herhangi bir abse veya enfeksiyon gelişmemiştir. Sonuç. Radio-Frekans (RF) tekniği karaciğer rezeksiyonunda kanamanın minimize edildiği bir ortam sağlamaktadır.

Anahtar sözcükler: Radyo-Frekans, karaciğer rezeksiyonu, hepatoma, travma

Geliş tarihi/Received: 12 Ocak 2014; Kabul tarihi/Accepted: 28 Nisan 2014

\section{*Corresponding author:}

Dr. Mustafa Turan, Genel Cerrahi Anabilim Dalı, Cumhuriyet Üniversitesi Tıp Fakültesi, TR58140 Sivas. E-mail: mturan9@gmail.com 


\section{Introduction}

Liver resection is nowadays done for a variety of primary or metastatic liver tumors, for benign liver disease, in liver trauma and for harvesting a graft in living related liver transplantation [1, 2]. Despite advances in surgical technique, liver resection still frequently results in significant blood loss with many patients requiring blood transfusion peri-or postoperatively [1].

A surgical technique, which includes the use of an energized instrument that can safely deal with transection of liver parenchyma and hemostasis at the same time, could possibly overcome these drawbacks. Radiofrequency (RF) devices have been used for more than a decade to thermoablate nonresectable hepatic lesions [3, 4]. Recently, a new concept was described, whereby RF is used to coagulate not the tumor itself but a thin zone of normal organ parenchyma surrounding it, to achieve near bloodless division of the parenchyma.

Probes of Radiofrequency assisted liver resection devices are mainly configurated as a single needle or in rod shape. For the period of four years, we are using a different RF device with a different probe configuration. This device has harrow-like 6-needle (electrode) RF probe (Figure 1). This equipment facilitated our liver resection procedures and decreased peroperative and post operative complications. Here, we report our experience with this new device.

\section{Material and methods}

This retrospective study, includes 16 patients who had RF-assisted liver resections between January 2009 and May 2013. Indications for liver resection were malignant tumors in 12 (Elective cases) and 4 patients with trauma etiology (Emergency cases) (Table 1).

Table 1. Clinical characteristics of the patients.

\begin{tabular}{|c|c|c|c|c|c|}
\hline \multicolumn{4}{|c|}{ Elective cases $(n=12)$} & \multicolumn{2}{|c|}{ Emergency cases $(n=4)$} \\
\hline Sex & $M *(n=10)$ & $W^{*}(n=7)$ & & $M(n=3)$ & $\mathbf{W}(\mathbf{n}=3)$ \\
\hline & \multicolumn{3}{|c|}{52.6 years (range $41-72$ years) } & \multicolumn{2}{|c|}{$\begin{array}{l}44.0 \text { years (range } 38-48 \\
\text { years) }\end{array}$} \\
\hline $\begin{array}{l}\text { Etiology of } \\
\text { resection }\end{array}$ & $\begin{array}{l}\text { Colorectal } \\
\text { metastases }(n=11)\end{array}$ & $\begin{array}{l}\text { Hepatocelluler } \\
\text { carcinoma, } \\
(n=4)\end{array}$ & $\begin{array}{l}\text { Over carcinoma } \\
\text { metastases } \\
(n=2)\end{array}$ & Traumatic bleedin & $\lg (n=6)$ \\
\hline Type of resection & $\begin{array}{l}\text {-Left lateral } \\
\text { segmentectomy } \\
(\text { segments II-III) } \\
(n=5) . \text { Non- } \\
\text { anatomical } \\
\text { resections }(n=6)\end{array}$ & $\begin{array}{l}\text {-Left lateral } \\
\text { segmentectomy } \\
(\text { segments II- } \\
\text { III) }(n=2) \text {. } \\
\text { Segment VI } \\
\text { resection }(n=2)\end{array}$ & $\begin{array}{l}\text {-Left lateral } \\
\text { segmentectomy } \\
(\text { segments II- } \\
\text { III) }(n=2)\end{array}$ & $\begin{array}{l}\text {-Non-anatomical } \\
\text { resection }(n=3) \text {. } \\
\text { Segment VI } \\
\text { resection }(n=2)\end{array}$ & $\begin{array}{l}\text { Type of } \\
\text { resection }\end{array}$ \\
\hline $\begin{array}{l}\text { Duration of RF } \\
\text { ablation } * *\end{array}$ & $34 \pm 5$ min. & & & $37 \pm 5$ min. & \\
\hline $\begin{array}{l}\text { Mean blood } \\
\text { loss** }\end{array}$ & $32 \pm 5 \mathrm{~mL}$ & & & $89 \pm 8 \mathrm{~mL}$ & \\
\hline $\begin{array}{l}\text { Postoperative } \\
\text { complications }\end{array}$ & $\begin{array}{l}\text { Pulmonary } \\
\text { complication } \\
(n=2)\end{array}$ & $\begin{array}{l}\text { Wound } \\
\text { infection }(n=1)\end{array}$ & $\begin{array}{l}\text { Biliary fistula } \\
(\mathrm{n}=1)\end{array}$ & $\begin{array}{l}\text { Pulmonary } \\
\text { complication } \\
(n=1)\end{array}$ & $\begin{array}{l}\text { Wound } \\
\text { infection } \\
(n=1)\end{array}$ \\
\hline $\begin{array}{l}\text { Intensive care } \\
\text { unit stay, days. } \\
* *\end{array}$ & $2 \pm 1$ days & & & $3 \pm 2$ days & \\
\hline $\begin{array}{l}\text { Duration of } \\
\text { hospitalization. } \\
* *\end{array}$ & $7 \pm 1$ days & & & $8 \pm 1$ days & \\
\hline
\end{tabular}


While there were 10 men and 7 women in Elective group, there are 3 men and 3 women in Emergency group. Mean age in Elective group was 52.6 years (range 41-72 years), and 44.0 years (range $38-48$ years) in Emergency group. In Elective group, nine patients had colorectal liver metastases, two had hepatocelluler carcinoma, and one had over carcinoma liver metastases. All patients operated were in Child's grade A.

All patients included in this study met the following criteria:

a. liver lesion or lesions that can be resected with adequate (R0) margins,

b. a sufficient amount of remnant functional liver parenchyma.

A standardized RF-assisted two-surgeon liver resection technique was done in all patients. The same three surgeons working in tandem performed all of the operations.

Under general anesthesia a midline incision with a right sagittal prolongation ( $\mathrm{J}$ incision) without opening the diaphragm is performed. Intra-abdominal adhesions and the falciform ligament are divided. A Thompson retractor is always used to ensure good exposure of the liver. The patient is in an anti-Trendelenburg position (15 head up). The tumor-containing liver lobe is mobilized in a standard way to the extent necessary for the intended resection, avoiding unnecessary liver mobilization and manipulation.

Intraoperative ultrasound, assisted by bimanual palpation, is done to determine the accurate position, extent, number of the tumors and their relation to the hepatic veins and glissonian pedicles. Inflow and outflow occlusion of the liver vessels, low CVP anesthesia, and topical hemostatic agents were not used during transection of the liver parenchyma. The upper and lower surface of the liver are marked with diathermy in order to provide a roadmap for the resection. Then, a harrow-like 6-needle (electrode) RF probe was applied to the liver through the resection margin (Figure 1). RF ablation (RFA) to the liver parenchyma to induce coagulative desiccation was carried out along this line with this probe and using a $470 \mathrm{kHz}$ generator (SURTRON SB, Laboratory for Electronic Design Spa, Aprilia, Italy). This probe performs a linear column-like affected zone with a total $12 \mathrm{~mm}$ width ( $6 \mathrm{~mm}$ on one side and $6 \mathrm{~mm}$ on the other side) in $4 \pm 1$ minutes. Once the tissue was ablated, the division of the liver parenchyma was completed using a surgical scalpel through the midline of the ablated tissue. Any bleeding from the resection margin during transection was ablated repeatedly until satisfactory hemostasis was achieved (Figure 1). The transection plane was then closely inspected for biliary leaks. All hepatic veins $>3 \mathrm{~mm}$ and suspected biliary structures at the plane of transection were ligated.

The plane of the division was performed in such a way as to leave a $1 \mathrm{~cm}$ resection margin away from the tumor. This safe margin was also confirmed with intraoperative serial frozen sections. Histopathological specimens were taken from the margin after piercing the probe to the liver. When the biopsy materials were taken, the RF generator was started and coagulation was performed. Histopathological examination of the resected specimen was also performed during the postoperative period in the Department of Pathology.

All patients were admitted to the intensive care unit during the postoperative period until their clinical status became better. All of them, after resection, underwent a Duplex ultrasonography of the liver postoperatively. One and two months after the procedure, the patients were invited to the hospital, and their physical examinations and routine analyses (complete blood count and biochemical and urine analyses) were performed. A repeat computerized tomography 1 month after the procedure was also performed.

In all patients, biochemical liver function tests were monitored before, on the 1st, 3rd, 5th and 8th day after liver resection. Liver sequestration, liver abscess, subphrenic abscess, bile leakage, sepsis, chest involvement and postoperative bleeding were considered procedure-related complications. When operating for colorectal cancer liver metastases, the RF-assisted technique facilitates non-anatomical, limited, tissue-sparing liver 
resection regardless whether the transection planes are straight or curved. The transection plane is molded according to the relation of the tumor to the hepatic veins and glissonian pedicles sparing as much unaffected liver parenchyma as possible. When operating for hepatocellular cancer, segment-oriented, anatomical liver resection, whenever possible, is preferred.

\section{Results}

The types of liver resection performed are listed in Table 1. Left lateral segmentectomy (segments II-III) was done in 9 patients. Segment VI resection was performed in 4 patients. Non-anatomical (wedge) resections were done in 10 patients.

The average time necessary for transection of the liver parenchyma was $34 \pm 5 \mathrm{~min}$. in Elective group and $37 \pm 5 \mathrm{~min}$. in Emergency group. Average blood loss was $32 \pm 5 \mathrm{~mL}$ in Elective group and $89 \pm 8 \mathrm{~mL}$ in Emergency group.

In the postoperative period, we did not see any subcapsular or perihepatic hematoma responsible for delayed hemorrhage. No signs of infectious disease or abscesses were observed. There were $6(26 \%)$ different postoperative complications (Table 1). The most frequent complication was pulmonary complication in 3 (13\%) patients). Two (8.6\%) patients had wound infection which were healed with wound care. There was no bleeding in the current serie. There was $1(4.3 \%)$ mild biliary fistula in this serie. This problem was resolved with medical treatment in one week. The mean hospital stay was $7 \pm 1$ days in Elective group, and $8 \pm 1$ days in Emergency group.

Serum Aspartate aminotransferase (AST) and Alanine transaminase (ALT) levels were increased in $100 \%$ of patients on postoperative 1st day $(\mathrm{p}<0.05)$. Mean ALT and AST levels were increased to $142 \pm 23$ and $154 \pm 29$ respectively, on postoperative 3rd day. $(\mathrm{p}<0.05)$. Later, these values were all started to decrease and 8 days after surgery ALT and AST levels have almost fully recovered ( $>0.05)$.

Seru alkaline phosphatase (ALP), Gamma-glutamyl transpeptidase (GGT) and bilirubine level differences of preoperative and postoperative period were not statistically significant $(p>0.05)$. While duration of hospitalization in Elective group was $7 \pm 1$ days, it is $8 \pm 1$ days in Emergency group. Mortality was zero, in this serie.

All of the patients, after resection, underwent a Duplex ultrasonography of the liver postoperatively, which showed normal blood flow within the splenic parenchyma and vessels. There was also detected no problem in the control examinations of the patients, which were performed 1 and 2 months after the procedure.

\section{Discussion}

Hepatic resection has evolved into the treatment of choice for selected patients with benign and malignant hepatobiliary disease [5]. Despite improvement in the safety of hepatic resection, the procedure is still associated with mortalities and postoperative complications, the most characteristic of which are liver insufficiency, biliary leaks, bleeeding and collections [6].

There are no anatomical planes in the liver through which bloodless transection of the parenchyma can be performed. Significant bleeding from the cut liver surface during transection is unavoidable and should be efficiently controlled. Commonly used methods for controlling bleeding are:

1. Pringle maneuver and low CVP anesthesia and

2. Surgical techniques for transecting the liver parenchyma-transection procedures, special instruments, energized instruments and topical hemostatic agents.

Main disadvantage of Pringle maneuver is that they can facilitate liver failure in patients suffering from chronic liver disease due to ischemia-reperfusion injury and that their use is time limited [7]. 
Rapid heating of liver tissue by RF causes protein denaturation, vessel wall injury, coagulation of the blood proteins and formation of an occlusive coagulum, resulting in tissue shrinkage and permanent 'welding' of all vascular and biliary branches. This principle is the basis of the Weber and Habib technique [8]. The liver tissue, along the resection line, is precoagulated by multiple full-thickness electrode insertions and an 'avascular' tissue plain is created. Dividing the liver along this clearly visible 'avascular' tissue plane with a surgical scalpel is virtually bloodless and no inflow or outflow clamping is necessary.

Probes of radiofrequency assisted liver resection devices are generally configurated as a single needle or in a rod shape. For the period of three years, we are using a different RF device (SURTRON SB) with a different probe configuration which has a harrow-like 6needle (electrode) RF probe (Figure 1). The probe of this equipment performs a linear column-like affected zone with a total $12 \mathrm{~mm}$ width $(6 \mathrm{~mm}$ on one side and $6 \mathrm{~mm}$ on the other side), resulting in a relatively small volume of damaged liver tissue. Other important advantage of this device is its shortness of application time. Each application to the liver and developing a column-like affected zone lasts in a mean of $4 \pm 1$ minutes. Overall, the average time necessary for transection of the liver parenchyma was $34 \pm 5$ min. in Elective group and $37 \pm 5$ min. in Emergency group. We think that, this equipment facilitated our liver resection procedures and decreased peroperative and post operative complications. Previously, we had also reported our succesful partial splenectomy cases performed with this device $[9,10]$.
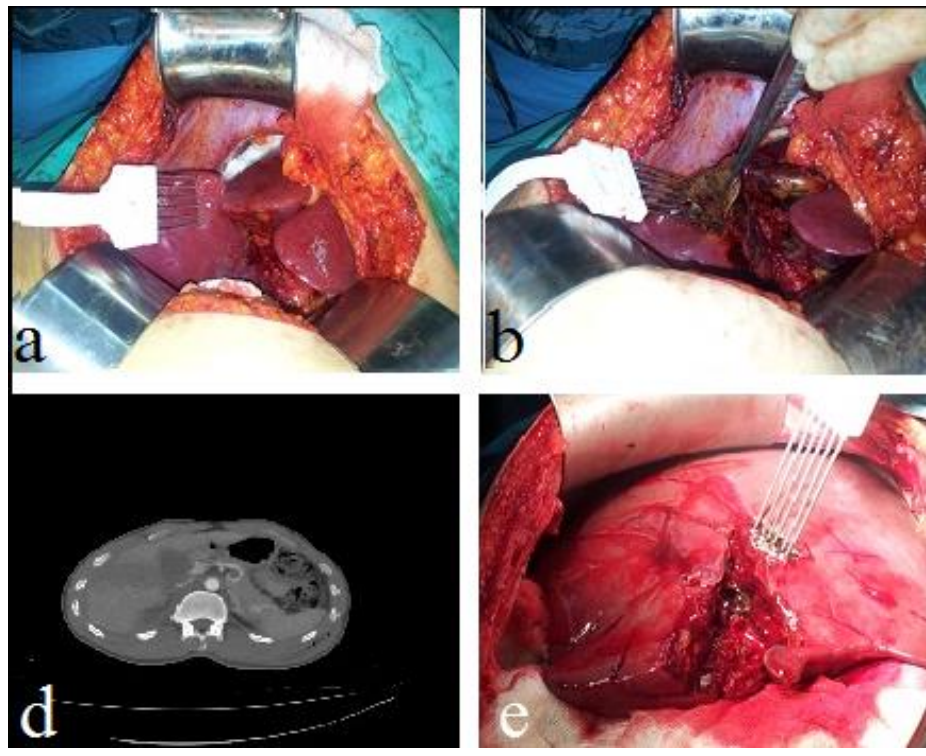
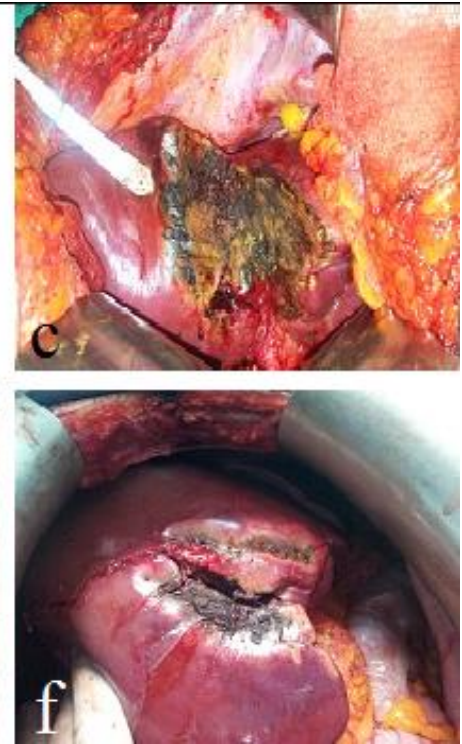

Figure 1 a, b, c. CT appearance of a patient who had previous cholcystectomy and histopathological examination revealed as adenocarcinoma. This patient had radical resection in segments $\mathrm{V}$ and $\mathrm{IV}$ of liver, 1d: CT appearance of a trauma patient with grade IV liver laceration, 1e: RF ablation to the bleeding parenchyma of liver, 1f: Bleeding was controlled and the appearance of liver after RF ablation.

In 6 trauma cases RF was used for coagulation purposes. In two of them while lacerated segment VI was resected, in other cases; non-anatomical liver resections in right lobe were performed succesfully with controlling the bleeding. There was no substantial blood loss related to the transection of the liver parenchyma. While average blood loss was $32 \pm 5 \mathrm{~mL}$ in Elective group, it was $89 \pm 8 \mathrm{~mL}$. in Emergency group. We think that bleeding controlling performance of this technique is satisfactory in suitable cases.

We had a bile leak in one case $(6 \%)$ which is similar to some of the large published series $[11,12]$. No signs of infectious disease or abscesses were observed. In the postoperative period, we did not see any subcapsular or perisplenic hematoma responsible for delayed 
hemorrhage. The mean hospital stay was $7 \pm 1$ days in Elective group, and $8 \pm 1$ days in Emergency group. These results also similar to some other series [13, 14].

Mean ALT and AST levels were increased to $142 \pm 23$ and $154 \pm 29$ respectively, on postoperative 3rd day $(\mathrm{p}<0.05)$. Later, these values were all started to decrease and 8 days after surgery ALT and AST levels have almost fully recovered ( $p>0.05)$. However these results showed that careful patient selection is important before RF application. If patient is in Child B or C using this technique repeatedly for multiple lesions may cause liver insufficiency.

In conclusion, we think that this RF assisted technique is effective in liver resections and allows the majority of liver resections to be performed nonanatomically. Atypical and typical liver resection can be safely performed without the need for inflow clamping or vascular exclusion. Preservation of normal liver parenchyma may have contributed to the low rate of liver insufficiency, but preoperative hepatic capacity is important before RF application.

\section{References}

1. Belghiti J, Hiramatsu K, Benoist S. Seven hundred forty-seven hepatectomies in the 1990s: An update to evaluate the actual risk of liver resection. J Am Coll Surg 2000; 191: 38-46.

2. Jarnagin WR, Gonen M, Fong Y. Improvement in perioperative outcome after hepatic resection: analysis of 1,803 consecutive cases over the past decade. Ann Surg 2002; 236: 397-406.

3. L.R. Jiao, P.D. Hansen, R. Havlik. Clinical short-term results of radiofrequency ablation in primary and secondary liver tumors. Am J Surg 1999; 177: 303-6.

4. G.S. Gazelle, S.N. Goldberg, L. Solbiati. Tumor ablation with radio-frequency energy Radiology 2000; 217: 633-46.

5. M.D. Finch, J.L. Crosbie, E. Currie. An 8-year experience of hepatic resection: Indications and outcome. Br J Surg 1998: 85: 315-9.

6. M. Cescon, G. Vetrone, G.L. Grazi. Trends in perioperative outcome after hepatic resection: Aanalysis of 1500 consecutive unselected cases over 20 years. Ann Surg 2009; 249: 995-1002.

7. Huguet C, Gavelli A, Bona S. Hepatic resection with ischemia of the liver exceeding one hour. J Am Coll Surg 1994; 178: 454-8.

8. Weber JC, Navarra G, Jiao LR. New technique for liver resection using heat coagulative necrosis. Ann Surg 2002; 236: 560-3.

9. Karadayi K, Turan M, Sen M. A New Partial Splenectomy Technique Using Radiofrequency Ablation Technology; report of a case. Surgical Practice 2010; 14: 147-9.

10. Karadayi K, Turan M, Sen M. A new technique for partial spleenectomy with radiofrequency technology. Journal of Surgical Laparoscopy, Endoscopy \& Percutaneous Techniques. 2011; 21: 358-61.

11. R.T. Poon, S.T. Fan, C.M. Lo. Improving perioperative outcome expands the role of hepatectomy in management of benign and malignant hepatobiliary diseases: Analysis of 1222 consecutive patients from a prospective database. Ann Surg 2004: 240; 698-708.

12. Imamura H, Seyama Y, Kokudo N. One thousand fifty-six hepatectomies without mortality in 8 years. Arch Surg. 2003; 138: 1198-206.

13. S T Fan, C M Lo, C L Liu. Hepatectomy for hepatocellular carcinoma: Toward zero hospital deaths. Ann Surg 1999; 229: 322-30.

14. Descottes B, Lachachi F, Durand-Fontanier S. Right hepatectomies without vascular clamping: Report of 87 cases. J Hepatobiliary Pancreat Surg 2003; 10: 90-4. 